\title{
THE MALAY CULTURAL LANDSCAPE CHARACTERISTICS FOR THE ISLAMIC ARISTOCRAT TOWN IN KELANTAN, MALAYSIA
}

Received July 30th, 2021 | Accepted November 19th, 2021 | Available online December 15th, 2021

DOl http://dx. doi. org/10.18860/jia.v6i4.13045 |

Nik Mastura Nik Mohammad

Department of Landscape and Architecture, UiTM Selangor

Malaysia

Email: nikma493@uitm.edu.my

\section{Nor Atiah Ismail}

Landscape Architecture Department,

Faculty of Design and Architecture,

Universiti Putra Malaysia

Malaysia

*Email: noratiah72@yahoo.com.sg

\section{Nangkula Utaberta}

Department of Architecture, Faculty of Civil Engineering and Built Environment, University Tun

Hussein Onn Malaysia

Malaysia

\begin{abstract}
The Malay cultural landscape has become an integral part of examining the cultural significance in Malaysia. Thus, the main objective of the study is to determine the impact of the visual characteristics of the built cultural landscape in conserving and preserving Kota Bharu as an aristocratic area in this modern era. Kota Bharu is one of the Islamic cities in Malaysia. This study embarks into a quantitative study using a mixed-method. A significant implication is to propose a significant model to value the Malay cultural heritage and preserve the culture and spirit among the Kelantanese Malay population who live in the modern era.
\end{abstract}

\section{KEYWORDS:}

Kelantanese Malay Traditional, Visual characteristic, Aristocrat area, Cultural landscape

\section{INTRODUCTION}

The ancient and historic areas have become a central issue over the past few decades-the Kelantanese Malay culture embedded in our historical, physical and spiritual aspects derived from the Kelantanese Malay community [1]. Today, it is sad to see that many heritages and cultural properties in Kota Bharu, Kelantan, are threatened, physically degraded, damaged, or destroyed, leading to less tangible physical characteristics of urban fabrics such as street patterns, people's activities, historical areas, open spaces, and natural features [2]. History has shown that Malaysia has experienced tremendous rapid economic growth due to increasing new development stereotypical landscapes. However, this development seems to have failed to meet the urban community's needs and lifestyles in the last three decades. Hence, it is essential to understand society's actions, attitudes, and perceptions towards studying the aristocrat enclave in Kota Bharu as a newly developed city in Malaysia. The Aristocrat area of Kota Bharu as a study area offers great heritage insights as many of the built cultural landscape characteristics in this area have significant historic city symbols that require further conservation for future generations [3]. It is part of the necessary process of examining places of cultural significance in Malaysia and developing these into heritage centers to be appreciated by the public and urban community [4].

The rapid population growth and intense development have created pressure and increased the areas of historic districts; thus, significant destruction of cultural heritage occurs. The past study also highlighted that the importance of citizen participation as the most significant factor in resolving issues was ignored [5][6]. Despite that, there is also a study by Sundra [7], which supported a need for Kota Bharu authority to monitor and control the rapid development that affected the first existence of this aristocrat enclave. The local distinctiveness of the aristocrat enclave shows how places around 100 years old acquire complexity in one's powerlessness and respond differently to their characters. Taylor [8] believed that the cultural landscape of the aristocrat enclave was the most challenged to their identity and uniqueness significance. He also summarizes that the cultural landscape can be an appropriate case between developing countries to investigate the role of the public in urban heritage conservation where the shreds of evidence can increase the role of community in the policy-making process. Therefore, it has become the primary intention of this study to evaluate urban historical fabrics that would lead to an empirical finding that emphasizes the role and function of individuals and some related issues in the decisionmaking and policy-making process in the cultural and historic aristocrat area of Kota Bharu in the modern era. This model is one of the ways to solve the issues of modern urban culture and heritage aristocrat areas in Kota Bharu. 
This research is focused on studying the challenges of maintaining historical built cultural landscape characteristics of aristocrat enclave in Kota Bharu. Urbanization problems in Kota Bharu are typically related to the intensity of human activities, an element of population density and movement. Some of these cultural heritage buildings and traditions faded away due to the nature of the rapid commercialization process; commercialization cities experienced historical challenges posed by rapid largescale urbanization business premises and other infrastructures [9]. A myriad of development activities taking place across the city have not left this city untouched. Modern structures of the skyscrapers encroached into the city and historical area. The palace is the administrative center, the mosque is a place of worship, and the market is to conduct commercial activities. The extensive urbanization and rapid development occurring in most historical towns have significantly eroded the identity of aristocrat enclave, sense of place, and physical attributes. Figure 1.0 displays the east coast economic region (ECER), including efforts to develop Kota Bharu. This effort is part of ECERDC's overall strategy to boost and strengthen the tourism sector in the Kota Bharu region. Commercial buildings and modern structures replace existing traditional villages without continuing with other remaining traditional surroundings [10].

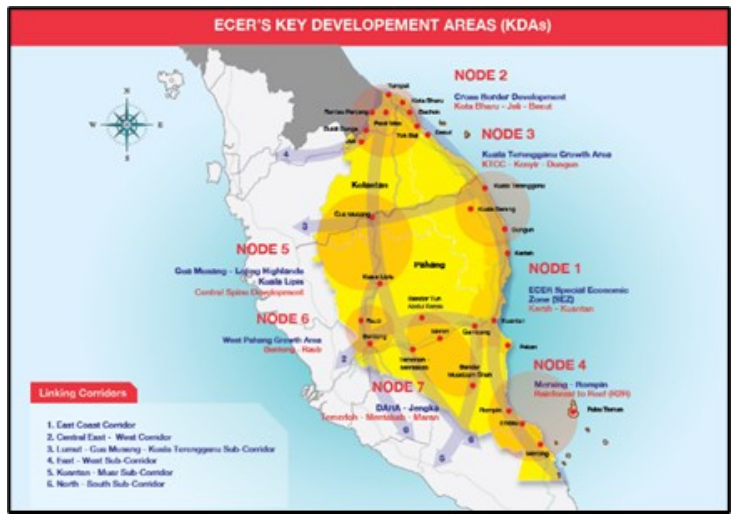

Figure 1.1: East Coast Economic Region ECER [11]

There is a need for Kota Bharu authority to monitor and control the rapid development that affected the first existence of this aristocrat enclave. Besides, the local distinctiveness of the aristocrat enclave shows how places around 100 years old acquire complexity in one's powerlessness and respond differently to their characters [5]. Regardless of climatic limitation, it has given more experience for this aristocrat enclave constraint to a tropical climate. However, the experience as a landscape architect indicates that any idea capacity to preserve a historic city influences the cultural landscape of aristocrat enclave as the most challenged for their identity and uniqueness significance [12][13].

Many historical sites in Kota Bharu rapidly lose their identity and sense of place because of rapid urbanization. This belief stems from the conviction that the success of rapid urbanization development projects has been significantly contributed in part by the rapid loss of identity of a sense of aristocrat place. The phenomenon of urban design and conservation and place quality research play the role in ensuring the place attachment as a component that gives the aristocrat place meaning. The importance of meaning in representing the imageability of a place is focused on identity and structure as a variable to achieve in research aim of this study.

\section{METHODOLOGY}

A focus group consisting of three government officers, one local authority, and four local leaders participated as respondents in this study. One of the study's significant findings found that Malaysia's built cultural landscape nominates that only ten percent of overall preservation and conservation development have given over to the aristocrat enclave's place attachment.

At the first stage, a documentary study focused on the improvement and renovation program at the aristocrat-built cultural landscape core of Kota Bharu [14]-[17]. This study evaluated this district's internal and external environment using an internal and external factors assessment matrix. The primary strategies of Aristocrat-built cultural landscape conservation have developed through the matrix of strengths, weaknesses, opportunities, and threats to determine appropriate strategy, while the current position of the historic core area was by using internal and external matrices. In this process, various sources were applied for identifying and analyzing the fourfold factors of the SWOT method, such as library sources and documents related to municipal power and boundaries, regional and national macro plans, and improvement and renovation plans of the historic core under consideration and the urban experts and authorities' views. Extreme tendencies towards modernism have taken out many particularities in the vitality and vibrancy in cities' Aristocrat-built cultural landscape core. These issues are often complex and worse in the historic cities of the Aristocrat-built cultural landscape than the other once. A physical, socio-economic, and cultural conditions of the historic city against current modern life led to negative and positive outcomes. Therefore, it is essential that identifying strengths and weaknesses will be able to reduce negative consequences. On the other hand, creating new opportunities and confronting serious threats will improve the approach of heritage conservation of the Aristocrat-built cultural landscape.

\section{Finding of the study}

1. Descriptive analysis:

Demographic analysis for this study. Research Objective 1: to analyze the challenges faced in terms of the characteristics of the built cultural landscape in selected aristocrat enclaves of Kota Bharu. The following is the finding and discussion based on the 
different locations selected in the aristocrat enclave of Kota Bharu.

\section{Major Finding on Objective 1:}

There are five factors identified on the built cultural landscape characteristics of aristocrat enclave of Kota Bharu, namely building facade/frontage, existing character (locality/genius loci), legibility (based on the layout of the place such as path, street, district, nodes, landmark), public realm (visually accessible, a network of high-quality streets, streetscapes, pedestrian), varieties/richness (detail use of materials). The result indicated that the area with the highest score for the case studies was located in Jalan Sultanah Zainab, Jalan Tengku Seri Akar, Jalan Sultan and Jalan Tengku Besar. Their indicators include existing locality, while the lowest as a public realm (visually accessible, a network of high-quality streets, streetscapes, pedestrian on the street vending activities functioned as the current place) with the lowest mean of 3.43

Meanwhile, the highest peak for the map is the element of existing characteristics. The items of historic city can respect the character of existing locality for Jalan Sultanah Zainab, which is 4.22 , with the highest being along Jalan Tengku Seri Akar, Jalan Sultan and Jalan Tengku Besar. The mean appears through three categories: environment quality and streetscape, heritage in view, as well as unique identity and characteristics. All the graphics which display Jalan Sultanah Zainab, Jalan Tengku Seri Akar, Jalan Sultan, and Jalan Tengku Besar and the rendering on the maps, show the highest, medium, and lowest score pattern in the case study area, which allows an analysis of the historic city conditions of the area based on three categories and discussed in the descriptive analysis.

This part of the research aims to identify the importance of preserving and conserving the values and meanings of the informant's descriptions to the visual characteristics of the built cultural landscape in aristocrat enclave. Talking to local and selected informants face-to-face, the method of the qualitativeinterview informant has enabled the researcher to obtain in-depth and rich data about visual characteristics of the built cultural landscape in aristocrat enclave. This paper addresses the themes derived from the research analysis, the retained memories and experiences of historic cities that have inspired urban residents to preserve and conserve the built cultural landscape in the aristocrat enclave. In the present historic city, the majority of the interviewees frequently referred to their past living experiences and passing by in the aristocrat enclave. This interconnection manifested itself in terms of royal event and the grandeur of the royalty of the historic city inspiration, elements in the aristocrat setting, and personal and emotional attachment. These manifestations support the contention in this study that the locals initiate their experiences in the built cultural landscape to enhance place attachment and place identity of the aristocrat enclave.

3. Major Finding on Objective 2:

For this study, Research Objective 2 is about the impact of visual characteristics of the built cultural landscape in conserving and preserving Kota Bharu as an aristocrat enclave with an Islamic value. The following is the finding and discussion based on the different locations selected in the aristocrat enclave of Kota Bharu. The benefit of the building façade style on the building image has the highest mean at 4.22. The building façade on physical variables is associated with each factor carried out during the first fieldwork of Jalan Sultanah Zainab, Jalan Tengku Seri Akar, Jalan Sultan and Jalan Tengku Besar, Kota Bharu, Kelantan. The historic city that can respect the 'character' of the current locality has the highest mean at 4.21. The existing characters can be found at Jalan Sultanah Zainab, Jalan Tengku Seri Akar, Jalan Sultan and Jalan Tengku Besar, Kota Bharu, Kelantan. The original historic building that influenced the city planning has the highest mean at 4.03. The legibility is at Jalan Sultanah Zainab, Jalan Tengku Seri Akar, Jalan Sultan and Jalan Tengku Besar, Kota Bharu, Kelantan. The public realms of connectivity and belonging as well as policy and practice produce a spirit of place as an inclusive and secure place to live, with the highest mean at 4.18. These public realms are found at Jalan Sultanah Zainab, Jalan Tengku Seri Akar, Jalan Sultan and Jalan Tengku Besar, Kota Bharu, Kelantan.

The objectives of heritage in the effort of conservation in many historical cities in Malaysia are still concentrating on the two main methods of identifying and protecting the built heritage like monuments and buildings. In the preceding discussion, the researcher attempted to show photographs as a tool and part of a qualitative approach record, buttressed by interviews and field notes. The lists of building from Badan Warisan Malaysia as a reading architecture that is documented for the visual tracing types and categorized the building area is to be discovered and strengthened the visual research. The objective is to document the visual of the scene to permit analysis in the research. The researcher repeated some of the pictures and took notes of why the photographs were. The following discussion presents the analysis of the photographic evidence to support the study.

\section{CONCLUSION AND RECOMMENDATIO}

Since the mid-1990s, with the increased focus on conserving Aristocrat-built cultural landscape historic cities, participatory planning has become a prominent topic in national and international meetings, conferences, and congresses worldwide. In this way, many principles and guidelines have provided and broadcast participatory approaches. They can improve urban heritage conservation and support professionals and decision-makers to address weaknesses and strengths as well as identify opportunities and threats. This paper examines the critical challenges in 
conserving Shiraz's historical and cultural city as a case study between Iran's historical cities via SWOT method of studying the aristocrat built cultural landscape Kota Bharu. The paper's findings demonstrate that some severe issues that affected Shiraz's Urban Heritage Conservation (UHC) are more complex than others. Partly, it implies that the most significant point is UHC management's weakness, namely the lack of a practical and legal mechanism of citizens' participation in UHC. Also, the greatest threat, which is the power imbalance in urban management and declining local power, was discussed. On the other hand, there are many opportunities to improve the UHC program. However, the most important is Shiraz, the cultural capital of Iran, as a re-portray of the Islamic Kota Bharu aristocrat-built cultural landscape perspectives.

\section{REFERENCES}

[1] T. S. H. M. Sheppard, "Traditional Malay House Forms in Terengganu and Kelantan", Journal of the Malayan Branch of the Royal Asiatic Society, vol.42, no.2, pp.1-9, 1969

[2] WUF ICOMOS, "Report of the Ninth Session of the World Urban Forum", World Federation of Engineering Organizations, 2018, available at https://www.wfeo.org/report-of-the-ninthsession-of-the-world-urban-forum/

[3] A. Hussein, Sejarah Tanah Melayu 1400-1963 (2nd Ed.), Kota Bharu: Pustaka Aman Press, 1964

[4] M. Badarudin, A. A. Ghafar, and B. Nurwati, Challenges of historic cities in the new millennium: Lesson from Malaysia. Unpublished conference paper. Universiti Sains Malaysia, 2000

[5] S. M. Zancheti, L. T. F. Hidaka, C. Ribero, \& B. Aguiar, "Judgement and validation in the Burra Charter process: introducing feedback in assessing the cultural significance of heritage sites", City \& Time, vol. 4, no. 2, pp. 47-53, 2009

[6] A. Watson, R. Matt, K. Knotek, D. R. Williams, L. Yung, "Traditional Wisdom: Protecting Relationships with Wilderness as a Cultural Landscape", Ecology and Society, vol. 16, no.1, 2011.

[7] R. Sundra, "The Malay Urban Tradition", in V. F. Chen, The Encyclopaedia of Malaysia Architecture. Kuala Lumpur: Archipelago Press, 1998.
[8] L. E. Taylor, The production of nature in planning for urban expansion: A cultural landscape study of new urban growth in Oakville, Ontario: University of Toronto, 2007

[9] A. Ezrin, Penempatan Serta Bandar-bandar Awal Di Tanah Semenanjung, Fakulti Alam Bina, Universiti Teknologi Malaysia. Unpublished, 1985

[10] N.H. Shuhaimi and N. A. Rahman, Early History: The Encyclopedia of Malaysia, Australia: Archipelago Press, 1998

[11] ECER, "Key Development Area", East Cost Economic Region, 2008, available at www.ecerdc.com.my.

[12] N. A. Ismail, N. Utaberta, M. Y. M. Yunos, S. Ismail, "Malay Cultural responsive Landscape: Inspiration for Design Emotion in Modern Landscape", Advances in Environmental Biology, vol. 9, no. 5, pp.480-484, 2015

[13] N. A., Ismail, N. Utaberta, M. Y. M. Yunos, S. Ismail, "A Cultural Responsive Landscape Study on Perak Malay Garden: An Expressional Value", Advances in Environmental Biology, vol. 9, no. 5, pp.485-490, 2015

[14] N. M. N. Mohammad, N. A. Ismail, S. Ismail, and N. F. M. Ariffin, "Understanding The Concept Of Sense of Place Within Cultural Landscape Setting", International Journal of Advanced Research (IJAR), vol 6, Dec, 2018, DOI: http://dx.doi.org/10.21474/IJAR01/8245

[15] N.M.N.Mohammad, M. Saruwono, S. Y. Said, W. A. H. W. Hariri, "A Sense of Place within Landscape Cultural Settings", Asian Journal of Environment-Behaviour Studies (ajE-Bs), vol. 3, no. 9, pp. 3-14, 2018, DOI: https:// doi.org/10.21834/aje-bs.v5i19.60

[16] N. M. N. Mohammad, S. A. A. Samah, A. M Muhammad, "Exploring the Communicative Capability Challenges of Architectural Undergraduates", Environment-Behaviour Proceedings Journal, Vol. 3, No. 8, pp. 3-11, 2018, doi: https://doi.org/10.21834/ebpj.v3i8.1405 